\title{
Five Serum Trace Elements Associated with Risk of Cardia and Non-cardia Gastric Cancer in a Matched Case-control Study
}

\section{Yulan Lin}

Fujian Medical University https://orcid.org/0000-0002-4208-9408

\section{Chuancheng Wu}

Fujian Medical University

\section{Wei Yan}

Fujian Xianyou Health and Family Planning Authority

\section{Saixiong Guo}

Fujian Xianyou County Hospital

\section{Baoying Liu ( $D$ liuby5@126.com )}

\section{Research article}

Keywords: Gastric cancer; serum elements; copper; zinc; selenium; molybdenum; iron; calcium; magnesium;

Posted Date: July 10th, 2019

DOI: https://doi.org/10.21203/rs.2.11172/v1

License: (9) This work is licensed under a Creative Commons Attribution 4.0 International License. Read Full License 


\section{Abstract}

Background: Serum trace elements have been some time suggested to influence the development of gastric cancer, but evidence is still lacking. Methods: In a case-control study from a high risk region of East China, all newly diagnosed patients with gastric cancer were compared with healthy controls 1:1 matched by sex, age ( \pm 3 years) and place of residence during 2013-2015. Results: A total of 299cases of gastric cancers, which included 122 cases of gastric cardia cancer (GCC) and 177 gastric non-cardia cancer (NCGC), and 299 healthy controls were included. Positive associations were found between serum copper and copper/zinc ratio and risk of overall gastric cancer (OR4th vs. 1 st quartile: $2.42,95 \%$ Cl: $1.10-$ 5.32 for copper, $p$ for trend=0.003; OR4th vs. 1 st quartile: $11.7,95 \% \mathrm{Cl}$ : 3.83-35.6 for copper/zinc ratio, $p$ for trend<0.0001), and for both GCC and NCGC subtypes. Serum selenium inversely associated with risk of NCGC (OR4th vs. 1 st quartile: $0.18,95 \% \mathrm{Cl}: 0.07-0.51$, p for trend=0.0001), while molybdenum seem to reduce risk of GCC (OR4th vs. 1st quartile: $0.12,95 \% \mathrm{Cl}: 0.03-0.47$, p for trend<0.0001). Strong inverse associations were also detected between serum calcium and risk of all groups of gastric cancer (all $p$ for trend $<0.05$ ). Although intermediate serum level of zinc and iron had lower risk of gastric cancer, no linear association was however found (all $p$ for trend $>0.05$ ). Conclusions: The current study present evidences for positive associations between copper, copper/zinc ratio and gastric cancer, as well as for inverse associations between serum selenium, molybdenum and calcium and risk of gastric cancer.

\section{Background}

Although the incidence has been decreasing in the past decades, gastric cancer remains globally the third most frequent cause of death from cancer. Incidence varies greatly among populations and is higher in Asian, Central and South America countries but low in North America and Western Europe.(1) Migration studies found lower incidence of gastric cancer among immigrants moved from high risk region to low risk region, which indicate that environmental factors play an important role in the development of gastric cancer. $(2,3)$ Furthermore, poor socioeconomic condition has been widely proven to relate with risk of gastric cancer. Higher incidence of gastric cancer were usually found in those regions with more infertile lands, high mountains, or excessive heave metals levels in soil, cereals and drinking water. Previous study confirmed that these environmental pollution by trace elements might contributed partly to their high incidence of gastric cancer.(4)

Some early studies have investigated the role of trace elements in the development of gastric cancer, however the results were inconsistent and mechanisms of effect of trace metal on gastric cancer are still far from being elucidated completely. Copper ( $\mathrm{Cu})$, zinc $(\mathrm{Zn})$ and selenium $(\mathrm{Se})$, iron ( $\mathrm{Fe})$, molybdenum (Mo), magnesium (Mg), and calcium (Ca) are essential trace metals and components of critical enzyme systems, playing key roles in maintaining DNA integrity by preventing oxidative DNA damage or affecting gene mutations.(5-7) The variations in these mineral levels are related to the incidence of several cancers. For example, Se has been studied for antioxidant and anticancer properties, $(8,9)$ especially against 
gastric cancer.(10) $\mathrm{Zn}$ is trace element found in blood, and most of it is contained in bones, skins, and hair (approximate 70\%). Inverse associations were also obtained between serum $\mathrm{Zn}$ and risk of gastric cancer in some early studies, $(11,12)$ but not all.(13) Higher level of $\mathrm{Cu}$ alone was also found significantly higher in cancerous human stomach in compared to normal samples.(14) More importantly, $\mathrm{Zn}$ and $\mathrm{Cu}$ are known as key cofactors in several enzymes, which include $\mathrm{Cu} / \mathrm{Zn}$ superoxide dismutases (SODs) decomposing superoxide radicals to $\mathrm{H}_{2} \mathrm{O}_{2}$ and playing a significant role against oxidant stress in several DNA repair proteins. $(15,16)$ Previous study has demonstrated that high serum levels of $\mathrm{Cu} / \mathrm{Zn}$ superoxide dismutase can be related with an increased gastric cancer risk.(17) A recent systematic review and meta-analysis gathered information on Fe (intake and serum status), and various cancer risk. Although it seems biologically plausible for Fe to be associated with gastric carcinogenesis, the evidence is rather heterogeneous and insufficients to lead to any conclusions.(18) Molybdenum (Mo) is an essential trace element that enters the body primarily from dietary sources. In humans, Mo is a cofactor for three enzyme classess-sulfite oxidase, aldehyde dehydrogenase, and xanthine oxidate.(19) There has been some evidences suggested that Mo deficiency could increase the risk of carcinogenesis especially in the gastrointestinal tract, but epidemiological evidences from humans are still lacking.(20)

In China, there is an obvious clustering of the geographical distribution of gastric cancer, with the highest mortality being mostly located in rural areas. Xianyou County in Putian City locates between east longitude $118^{\circ} 27^{\prime}-118^{\circ} 56^{\prime}$ and north latitude $25^{\circ} 11^{\prime}-25^{\circ} 43^{\prime}$ on the southeast coast of Fujian province, China, and has an estimated population of 2.1 million in the year 2012. In this county, gastric cancer was the dominant leading cause of death, explaining $30.43 \%$ of total cancer death, and the death rate reached as high as $73.93 \%$ with an average survival time of 22 months in 2012.(21) The standardize mortality rate of gastric cancer was 49.47/100,000 in Xianyou County, which was 2.23-fold higher than the Chinese national average $(21.9 / 100,000)$.(21) Standardized mortality rate of gastric cancer in Xianyou County closely related to geographical distributions of mountain, plain and coastal regions. Mountain areas were observed with the highest mortality rate $(94.4 / 100,000)$, in compared to the lowest rate observed in coastal regions $(26.4 / 100,000)$ (data not shown). More interesting, we recently detected discrepancies of $\mathrm{Cu}, \mathrm{Zn}, \mathrm{Se}, \mathrm{Mo}, \mathrm{Fe}, \mathrm{Ca}$, and $\mathrm{Mg}$ in soil, water or rice between these various regions with different gastric cancer incidences in Xianyou County, which indicate the potential associations between risk of gastric cancer and environmental trace elements.(22) In line with this finding, an earlier study also confirmed lower serum level of $\mathrm{Zn}$ and higher level of $\mathrm{Cu} / \mathrm{Zn}$ ratio in healthy population in Putian City in compared to that of other regions in Fujian province with lower incidence of gastric cancer.(23)These evidences indicate that trace elements variations might play an important role in the development of gastric cancer in this area. However, to date, no large-scale epidemiological studies have proved the association between serum level of these trace elements and risk of gastric cancer in Xianyou County. Thus, the aim of this study was to investigate whether the serum concentrations of trace elements $\mathrm{Cu}, \mathrm{Zn}, \mathrm{Se}, \mathrm{Mo}, \mathrm{Fe}$, $\mathrm{Ca}, \mathrm{Mg}$ and $\mathrm{Cu} / \mathrm{Zn}$ ratio are associated with gastric cancer risk, thus explain partly the high incidence of gastric cancer in Xianyou County. 


\section{Methods}

\section{Study Design and Population}

A population-based case-control study was conducted in Xianyou County between March 2013 and December 2015. All newly diagnosed cases of gastric cancer in Xianyou County Hospital were identified. All individuals who were aged $\geq 18$ years and have lived in Xianyou for at least 10 years were eligible and recruited in Xianyou County Hospital. Gastric cancer was defined according to the International Classification of Diseases, 10th Revision (ICD-10) code, and was sub-classified as gastric cardia cancer (GCC) if they involved the esophagogastric junction and as non-cardia gastric cancer (NCGC) if they did not. Patients who had a history of any cancer, mental illness, and those unable to complete the questionnaire were excluded. Controls were individually matched $(1: 1)$ to cases based on sex, age $( \pm 3$ years), and place of residence. They were required to live in the same town or a town with a similar incidence of gastric cancer, and were required to be living in Xianyou County for at least 10 years with no prior history of gastric cancer. Matched controls were randomly selected by the Health department of Xianyou County Government, who was responsible to send study invitation letters to eligible controls. Data was collected from all consenting and participating subjects at Xianyou County Hospital. The study was approved by the ethics committees at Xianyou County Hospital and Fujian Medical University. Written consents were obtained from all participants at the study enrollment.

\section{Data Collection}

All cases and controls were personally face-to-face interviewed by trained research nurses from Xianyou County Hospital. A structured and standard questionnaire consisting of 337 items under 8 categories was used for the data collection. The questionnaires included following categories: (i) demographic factors (16 items), including the subject's age, height, weight, marital status, education level, monthly income, etc.; (ii) occupational history (17 items), including profession, pesticide exposure at work, etc.; (iii) lifestyles (70 items), including smoking habits, use of alcohol, tea consumption, etc.; (iv) dietary intake (140 items); (v) ) personal medical history (33 items), including personal disease records, medication, etc.; (vi) family cancer history (18 items), including family history (first and second-degree relatives) of any cancer, gastric cancer and esophageal cancer;(vii) mental health (9 items);(viii) cancer related diagnoses and treatment (34 items), including surgery, chemotherapy, and radiotherapy, etc. Smoking habit was defined as consuming at least one cigarette per day during the last 6 months or longer.

\section{Laboratory Test}

Approximately $5 \mathrm{~mL}$ of venous blood was collected into an element-free vacuum blood tube without anticoagulation in Xianyou County Hospital. After centrifugation, serum samples were prepared and pre- 
served at a temperature of $-20^{\circ} \mathrm{C}$ prior to analyses. The serum concentration of all trace elements were analyzed using in- ductively coupled plasma mass spectrometry (ICP-MS; Elmer NexION 350X, USA).

\section{Statistical Analysis}

Since most of the serum concentrations of trace elements were not normally distributed, we used median and interquartile range to describe them. Chi-square test was used for the comparisons of categorical variables. The T-test (normally distributed) and Wilcoxon rank-sum test (non-normally distributed) were used for the comparisons of continuous variables. To assess the effect of trace elements on the risk of gastric cancer, conditional logistic regression was used to estimate crude and adjusted odd ratios (ORs) and their $95 \%$ confidence intervals (Cls). Serum concentrations of trace elements were classified into quartile based on levels of controls. We adjusted for potential confounding factors including age group ( $<45,45-55,56-65,66-75, \geq 76$ years), sex (male, female), body mass index (BMI, $<18,5,18.5-24.9, \geq 25$ $\mathrm{kg} / \mathrm{m}^{2}$ ), education level ( $\leq 7,7-9, \geq 10$ years), occupation (farmer, industrial worker, office worker, others), household income ( $<600,600-1000, \geq 1000$ Chinese Yuan/month/person), smoking (yes, no), chronic atrophic gastritis (yes, no) and family history of gastric cancer (yes, no). We also conducted subgroup analysis according to tumor localization: GCC vs. NCGC using conditional logistic regression, and applied the Wald test to assess heterogeneity of the ORs. Two-sided $p<0.05$ was regarded as having statistical significance. SAS 9.4 was used for all statistical analyses.

\section{Results}

\section{Baseline}

A total of 299 cases of gastric cancer were included in the final analysis, consisting of GCC $(n=122)$ and NCGC $(n=177)$ patients. The number of sex, age and resident town-matched controls was 299 (Table 1). Cases had lower BMI than controls (all $p<0.05$ ). Meanwhile, they were observed with lower education level but higher household income in compared to controls (all $p<0.05$ ). Higher prevalence of chronic atrophic gastritis was observed in both GCC (23.8\%) and NCGC (18.6\%) in compared to GCC (7.4\%) (all $p<0.05)$.

\section{Distributions of Trace Elements}

Median serum concentration of Cu was observed much lower in control groups (927.7 $\mu \mathrm{g} / \mathrm{L}$, interquartile range 799.1-1312.5 $\mu \mathrm{g} / \mathrm{L})$ in compared to both GCC $(1014.6 \mu \mathrm{g} / \mathrm{L}$, interquartile range 874.4-1309.2 $\mu \mathrm{g} / \mathrm{L})$ and NCGC $(1000.2 \mu \mathrm{g} / \mathrm{L}$, interquartile range 821.4-1226.3 $\mu \mathrm{g} / \mathrm{L})$ (all $p<0.05)$ (Table 2). Cu/Zn ratio was also observed higher in GCC (median=2.16) and NCGC (median=1.91) than controls (median=1.43) (all $p<0.05)$. Median serum concentrations of $\mathrm{Mo}(1.8 \mu \mathrm{g} / \mathrm{L}$ in controls $v s .0 .93 \mu \mathrm{g} / \mathrm{L}$ in GCC and $0.93 \mu \mathrm{g} / \mathrm{L}$ in NCGC) and $\mathrm{Ca}(85.1 \mu \mathrm{g} / \mathrm{L}$ in controls $v s .66 .7 \mu \mathrm{g} / \mathrm{L}$ in GCC, and $68.9 \mu \mathrm{g} / \mathrm{L}$ in NCGC) observed in controls were significantly lower than all gastric cancer groups (all $p<0.05$ ). Meanwhile, the distributions of $\mathrm{Zn}, \mathrm{Se}$ and $\mathrm{Mg}$ were similar between controls and gastric cancer cases (all $p>0.05$ ). 


\section{Serum Trace Elements in Relation to Gastric Cancer}

Highest level of Cu was observed with an OR of 2.42 (95\% Cl: 1.10-5.32) for overall gastric cancer risk in compared to the lowest group (Table 3). Although higher point estimates were also observed in the highest level of $\mathrm{Cu}$ among patients with either GCC or NCGC subtypes, no statistically significance was observed. Dose-response correlations were observed between serum level of $\mathrm{Cu}$ and all subtypes of gastric cancer (all $p$ for trend<0.05). Study subjects with intermediate level of Zn (quartile 3: 650.2-844.5 $\mu \mathrm{g} / \mathrm{L}$ ) were observed with lower risk of gastric cancer combined (OR=0.25, 95\% Cl: 0.10-0.61), GCC $(\mathrm{OR}=0.15,95 \% \mathrm{Cl}: 0.03-0.43)$ and $\mathrm{NCGC}(\mathrm{OR}=0.34,95 \% \mathrm{Cl}: 0.13-0.98)$. However, no dose-response association was observed in any of case groups (all $p>0.05$ ).

Highest serum level of Se inversely associated with risk of gastric cancer combined $(\mathrm{OR}=0.33,95 \% \mathrm{Cl}$ : $0.15-0.75)$, and this association seems to limit in NCGC subtype (OR=0.18, 95\% Cl: $0.07-0.51)$. A doseresponse association was observed between serum Se concentration and gastric cancer combined ( $p$ for trend=0.009), as well as NCGC ( $p$ for trend=0.0001). No associations were observed for GCC ( $p$ for trend=0.43). Comparing the highest to the lowest quartiles of Mo biomarkers, we found statistically inverse associations between serum Mo and overall risk of gastric cancer ( $\mathrm{OR}=0.06,95 \% \mathrm{Cl}: 0.02-0.20)$ and GCC (OR=0.12, 95\% Cl: 0.03-0.47). Dose-response associations were found for all three case groups (all $p$ for trend $<0.05$ ).

No dose-response association was found for Fe in relation to any gastric cancer groups. However, higher serum $\mathrm{Fe}$ was observed with more than $50 \%$ reduction in gastric cancer combined in compared to the reference level $\left(\mathrm{OR}_{3 \mathrm{rd}}\right.$ quartile $\left.=0.27,95 \% \mathrm{Cl}: 0.11-0.68 ; \mathrm{OR}_{4 \text { th quartile }}=0.41,95 \% \mathrm{Cl}: 0.18-0.91\right)$. More specific, this risk reduction by Fe might only affect GCC patients $\left(\mathrm{OR}_{3 \mathrm{rd} \text { quartile }}=0.18,95 \% \mathrm{Cl}: 0.05-0.70\right)$. Higher serum concentration of $\mathrm{Ca}$ was inversely associated with risk of all gastric cancer groups. In compared to the lowest quartile of $\mathrm{Ca}$, the $\mathrm{OR}$ calculated in the highest quartile was 0.04 (95\% $\mathrm{Cl}$ : 0.01-0.11) for risk of gastric cancer combined, 0.06 (95\% Cl: 0.01-0.26) for GCC risk, and 0.02 (95\% Cl: 0.00-0.17) for NCGC. Dose-response was observed between serum level of $\mathrm{Ca}$ and all gastric cancer groups (all $p$ for trend $<0.05)$. No significant association was observed for serum level of $\mathrm{Mg}$ in relation to gastric cancer risk. Study subjects with the highest $\mathrm{Cu} / \mathrm{Zn}$ ratio had more than 10 -fold increased risk of gastric cancer combined (OR=11.70, 95\% Cl: 3.83-35.6), GCC (OR=9.03, 95\% Cl: 2.29-35.6) and NCGC (OR=18.82, 95\% Cl: 3.50-96.01) subtypes. Dose-response was observed for all gastric cancer groups (all $p$ for tend $<0.05$ ).

\section{Discussion}


The current study mainly reveals the role of eight serum trace elements in the development of gastric cancer. The results demonstrated strong inverse associations between serum concentrations of Se, Mo, $\mathrm{Ca}$ and risk of gastric cancer. Meanwhile, high serum concentrations of $\mathrm{Cu}$ and $\mathrm{Cu} / \mathrm{Zn}$ ratio related to increased risk of gastric cancer. Although decreased risks of gastric cancer were also observed in higher serum level of $\mathrm{Zn}$ and $\mathrm{Fe}$, no dose-response associations were found.

The data from the present study are consistent with the impression that high serum Se may be associated with decreased risk of gastric cancer. Previous studies have shown that Se may have anticarcinogenic effects, especially against cancers of lung, prostate, skin and gastrointestinal system.(24, 25) One study observed significant lower serum levels of Se in esophageal cancer group, as compared with normal healthy controls.(26) A nutrition intervention trail conducted in Linxian County among general population observed lower mortality of gastric cancer in participant groups receiving supplementation with vitamins and minerals (including Se) than individuals who did not receive the supplements.(27) Of note, Linxian County is also a rural area with poor socioeconomic status and wellknown for its high incidence of gastric cancer, which is very similar to the study region of the current study.(28) Furthermore, it worth mention that, the inverse association between Se level and gastric cancer may only occur in populations with low Se levels.(29) Serum level of Se below $70 \mu \mathrm{g} / \mathrm{L}$ is usually considered as deficiency.(30) According to this standard, $25.4 \%$ of our controls (76/299) and $34.1 \%$ of all gastric cancer cases (102/299) were considered to be Se deficient. It could be inferred that low level of Se might contribute partly to high incidence of gastric cancer found in Xianyou County.

Essential elements $\mathrm{Cu}$ and $\mathrm{Zn}$ have a role in many biochemical reactions as a micro-source.(31) Zn alone has been associated with risk of gastric cancer, but the epidemiological finding have been quite limited and controversial. Zhang et al. have also observed higher serum concentration of $\mathrm{Zn}$ in gastric cancer cases than healthy controls.(12) However, a Japanese study found no excess risk of gastric cancer among those with the lowest levels of $\mathrm{Zn}(\mathrm{OR}=1.2)$.(13) Although in our study, decreased risks of gastric cancer were found in the third quartile of serum $\mathrm{Zn}$, the linear association was not statistically significant. On the other hand, higher level of Cu was also observed associated with higher risk of gastric cancer in the current study. Our result is partly supported by previous studies which detected higher level of $\mathrm{Cu}$ in gastric cancer cases in compared to health controls.(32) It has been known that Cu participates in the reductive activation of $\mathrm{H}_{2} \mathrm{O}_{2}$, causing damage to cellular DNA, proteins and lipids. The interaction of $\mathrm{H}_{2} \mathrm{O}_{2}$ with $\mathrm{Cu}$ generates more reactive oxygen species, such as hydroxyl radicals. These reactive oxygen species have been considered as being responsible for the process of carcinogenesis.(33) More importantly, our results demonstrated that high $\mathrm{Cu} / \mathrm{Zn}$ ratio could be a strong risk factor of gastric cancer. Disturbances of blood $\mathrm{Zn}$ and $\mathrm{Cu}$ concentrations have been previously observed in many types of cancers including head and neck, gastrointestinal, and bladder carcinomas, and the $\mathrm{Cu} / \mathrm{Zn}$ ratio was also suggested as a biochemical marker of cancer prognosis.(32, 34-37) 
Our results found limited evidences for the association between serum Fe status and GCC and all gastric cancer combined, which is partly consistent with those from previous studies. In the European Prospective Investigation into Cancer and Nutrition (EPIC) study, inverse dose-response associations were found between serum Fe and overall risk of gastric cancer $\left(\mathrm{OR}_{4 \text { th }}\right.$ s. 1st quartile $=0.62,95 \% \mathrm{Cl}: 0.44-0.88, p$ for trend=0.034), as well as $\mathrm{NCGC}\left(\mathrm{OR}_{4 \text { th }}\right.$ s. 1 st quartile $=0.54,95 \% \mathrm{Cl}: 0.33-0.89, p$ for trend $\left.=0.029\right)$. (38) Similarly, a Finnish men cohort study also found serum Fe had an inverse, or possibly "u" shaped relationship with this malignancy in the NCGC site $\left(\mathrm{OR}_{3 r d} v s .1\right.$ st quartile $=0.39,95 \% \mathrm{Cl}: 0.19-0.78, p$ for trend=0.06), although the trend analysis was not statistically significant.(38) In another Finnish cohort study, which involved 120 incident male gastric cancers and 76 female gastric cancers, the relationship in males was statistically significant $\left(\mathrm{RR}_{4 \text { th }} v\right.$ s. 1 st quartile $=0.60, p$ for trend<0.01).(39)

The present study also observed lower risk of gastric cancer, regardless of GCC or NCGC, in the higher quartile of serum Mo, indicating the protective role of Mo in the development of these diseases. However, little evidence exists to explain the effects of serum Mo on gastric cancer. An earlier Chinese study showed that serum Mo levels of 33 patients with gastric cancer were significantly lower than those of 77 healthy controls.(20) Similarly, a recent published Chinese study found that serum Mo concentration tended to be lower in H.pylori-infected participants than those un-infected, although no statistically significant differences were actually observed.(40) Due to the scare epidemiological data, the appropriate amount of serum Mo in human warrants further investigations.

Extensive epidemiological evidence has indicated the protective role of dietary calcium or Vitamin D against gastrointestinal cancer, including gastric cancer. $(41,42)$ However, how serum calcium influence gastric cancer remains indefinite. A large scale Swedish cohort study evaluated serum calcium status in 782 incident gastric cancers.(43) Although lower ORs were observed in the higher quartiles of serum calcium, no statistically significant association was found.

Some methodological issues of our study deserve attention. The strengths include the large sample size; individual matching for age, sex and resident region by gastric cancer risk; the standardized tumor classification; the personal interviews with all study participants in a standard and strict manner; and stratified analysis by different gastric cancer localization. Meanwhile, our study has some limitations that should be described. A major concern is that we were not able to adjust to H. pyloric infection, which might potentially cause confounding effect on the association between serum trace elements and gastric cancer, especially NCGC. However, the availability of chronic atrophic gastritis help to reduce the potential confounding effect, as $\mathrm{H}$. pyloric infection was believed to cause NCGC through causing gastritis and gastric atrophy. (44) Another concern is the possibility of exposure misclassification using a 
questionnaire that has not been validated. However, the reliability rate of our questionnaire was estimated as high as $97 \%$, suggesting the potential of high accuracy in measuring risk factors (data not shown).

\section{Conclusions}

The presence of associations between gastric cancer and serum level of trace elements is observed in the present study. We suggest that lower levels of $\mathrm{Se}, \mathrm{Mo}$ and $\mathrm{Ca}$ and higher levels of $\mathrm{Cu}$ and $\mathrm{Cu} / \mathrm{Zn}$ ratio may play an important role in gastric cancer induction. High risk regions, especially those found with environmental contamination of toxic trace elements should enhance preventive implement against gastric cancer. It need to be noted that, due to inevitable bias in retrospective study, further prospective studies are required to clarify the association between the different stages of gastric cancer and serum trace element levels.

\section{Abbreviations}

GCC: Gastric cardia cancer

NCGC: Non-cardia gastric cancer

\section{Declarations}

\section{Ethics Approval and Consent to Participate}

This study was conducted according to the guidelines laid down in the Declaration of Helsinki and all procedures involving human subjects/patients were approved by the Xianyou County Hospital and Fujian Medical University. Written informed consent was obtained from all subjects/patients at the study enrollment.

\section{Consent to Publish}

Not applicable

\section{Availability of Data and Materials}

The dataset analysed during the current study are not publicly available due to that it concern personal information of study participants, but are available from the corresponding author on reasonable request. 


\section{Competing Interests}

The authors declare that they have no conflict of interest.

\section{Funding}

This work was supported by the Natural Science Foundation of Fujian Province, China (Grant No. 2015J01673; 2017J01811; 2018J01825); Fujian Innovative Medicine (Grant No. 2016-CX-41); Xianyou County Government of Putian, Fujian, China (Grant No. 2013B008); Cultivation Program for Distinguished Young Scholar of Fujian Province(Grant No. 2017B020); and Fujian Medical University's Research Foundation for Talented Scholars (Grant No. XRCZX2017012). All these funding did not involve in study design and collection, data analysis, and manuscript writing.

\section{Authors' Contributions}

The authors' contributions to this study were as follow: study design, CW, WY, SG, and BL; data collection, $\mathrm{CW}, \mathrm{WY}, \mathrm{SG}$, and BL; statistical analysis YL; interpretation of results and manuscript writing by all authors. None of authors had a personal or financial conflict of interest.

\section{Acknowledgments}

We appreciate all study participants and research investigators, students during the entire study period.

\section{References}

1. Parkin DM, Bray F, Ferlay J, Pisani P. Global cancer statistics, 2002. CA: a cancer journal for clinicians. 2005;55(2):74-108.

2. Kolonel LN, Nomura AM, Hirohata T, Hankin JH, Hinds MW. Association of diet and place of birth with stomach cancer incidence in Hawaii Japanese and Caucasians. The American journal of clinical nutrition. 1981;34(11):2478-85.

3. Haenszel W, Kurihara M. Studies of Japanese migrants. I. Mortality from cancer and other diseases among Japanese in the United States. Journal of the National Cancer Institute. 1968;40(1):43-68.

4. Khlifi R, Olmedo P, Gil F, Hammami B, Chakroun A, Rebai A, et al. Arsenic, cadmium, chromium and nickel in cancerous and healthy tissues from patients with head and neck cancer. The Science of the total environment. 2013;452-453:58-67. 
5. Ho E. Zinc deficiency, DNA damage and cancer risk. The Journal of nutritional biochemistry. 2004;15(10):572-8.

6. Patrick L. Selenium biochemistry and cancer: a review of the literature. Alternative medicine review : a journal of clinical therapeutic. 2004;9(3):239-58.

7. Uriu-Adams JY, Keen CL. Copper, oxidative stress, and human health. Molecular aspects of medicine. 2005;26(4-5):268-98.

8. Ramoutar RR, Brumaghim JL. Antioxidant and anticancer properties and mechanisms of inorganic selenium, oxo-sulfur, and oxo-selenium compounds. Cell biochemistry and biophysics. 2010;58(1):123.

9. Nelson WG, De Marzo AM, Isaacs WB. Prostate cancer. The New England journal of medicine. 2003;349(4):366-81.

10. Nouarie M, Pourshams A, Kamangar F, Sotoudeh M, Derakhshan MH, Akbari MR, et al. Ecologic study of serum selenium and upper gastrointestinal cancers in Iran. World journal of gastroenterology. 2004;10(17):2544-6.

11. Campos Fl, Koriyama C, Akiba S, Carrasquilla G, Serra M, Carrascal E, et al. Toenail zinc level and gastric cancer risk in Cali, Colombia. Journal of cancer research and clinical oncology. 2008;134(2):169-78.

12. Zhang WH, Wu XJ, Niu JX, Yan H, Wang XZ, Yin XD, et al. Serum zinc status and Helicobacter pylori infection in gastric disease patients. Asian Pacific journal of cancer prevention : APJCP. 2012;13(10):5043-6.

13. Kabuto M, Imai H, Yonezawa C, Neriishi K, Akiba S, Kato H, et al. Prediagnostic serum selenium and zinc levels and subsequent risk of lung and stomach cancer in Japan. Cancer epidemiology, biomarkers \& prevention : a publication of the American Association for Cancer Research, cosponsored by the American Society of Preventive Oncology. 1994;3(6):465-9.

14. Kohzadi S, Sheikhesmaili F, Rahehagh R, Parhizkar B, Ghaderi E, Loqmani H, et al. Evaluation of trace element concentration in cancerous and non-cancerous tissues of human stomach. Chemosphere. 2017; 184:747-52.

15. Murakami M, Hirano T. Intracellular zinc homeostasis and zinc signaling. Cancer science. 2008;99(8):1515-22.

16. Lowndes SA, Adams A, Timms A, Fisher N, Smythe J, Watt SM, et al. Phase I study of copper-binding agent ATN-224 in patients with advanced solid tumors. Clinical cancer research : an official journal of the American Association for Cancer Research. 2008;14(22):7526-34.

17. Lin Y, Kikuchi S, Obata Y, Yagyu K, Tokyo Research Group on Prevention of Gastric C. Serum copper/zinc superoxide dismutase (Cu/Zn SOD) and gastric cancer risk: a case-control study. Japanese journal of cancer research : Gann. 2002;93(10):1071-5.

18. Fonseca-Nunes A, Jakszyn P, Agudo A. Iron and cancer risk-a systematic review and meta-analysis of the epidemiological evidence. Cancer epidemiology, biomarkers \& prevention : a publication of the 
American Association for Cancer Research, cosponsored by the American Society of Preventive Oncology. 2014;23(1):12-31.

19. Kisker C, Schindelin H, Rees DC. Molybdenum-cofactor-containing enzymes: structure and mechanism. Annual review of biochemistry. 1997;66:233-67.

20. Cao GH, Yan SM, Yuan ZK, Wu L, Liu YF. A study of the relationship between trace element Mo and gastric cancer. World journal of gastroenterology. 1998;4(1):55-6.

21. Li D, Wu C, Cai Y, Liu B. Association of NFKB1 and NFKBIA gene polymorphisms with susceptibility of gastric cancer. Tumour biology : the journal of the International Society for Oncodevelopmental Biology and Medicine. 2017;39(7):1010428317717107.

22. Xiao LW, Liu BY, Wu CC, Chen Y, Li HT, Yan W, et al. A case control study on presence of chemical elements in plasma of gastric cancer patients. Journal of Environmental \& Occupational Medicine,2017,34(8):703-706. (Article in Chinese).

23. Lu HD, Wang ZQ, Pan YR, Zhou TS, Xu XZ, Ke TW. Comparison of serum Zn, Cu and Se contents between healthy people and patients in high,middle and low incidence areas of gastric cancer of Fujian Province. World journal of gastroenterology. 1999;5(1):84-6.

24. Rayman MP. Selenium in cancer prevention: a review of the evidence and mechanism of action. The Proceedings of the Nutrition Society. 2005;64(4):527-42.

25. Lee SR, Bar-Noy S, Kwon J, Levine RL, Stadtman TC, Rhee SG. Mammalian thioredoxin reductase: oxidation of the C-terminal cysteine/selenocysteine active site forms a thioselenide, and replacement of selenium with sulfur markedly reduces catalytic activity. Proceedings of the National Academy of Sciences of the United States of America. 2000;97(6):2521-6.

26. Goyal MM, Kalwar AK, Vyas RK, Bhati A. A study of serum zinc, selenium and copper levels in carcinoma of esophagus patients. Indian journal of clinical biochemistry : IJCB. 2006;21(1):208-10.

27. Qiao YL, Dawsey SM, Kamangar F, Fan JH, Abnet CC, Sun XD, et al. Total and cancer mortality after supplementation with vitamins and minerals: follow-up of the Linxian General Population Nutrition Intervention Trial. Journal of the National Cancer Institute. 2009;101(7):507-18.

28. Yang L. Incidence and mortality of gastric cancer in China. World journal of gastroenterology. 2006;12(1):17-20.

29. Koriyama C, Campos FI, Yamamoto M, Serra M, Carrasquilla G, Carrascal E, et al. Toenail selenium levels and gastric cancer risk in Cali, Colombia. The Journal of toxicological sciences. 2008;33(2):227-35.

30. Dietary Reference Intakes for Vitamin C, Vitamin E, Selenium, and Carotenoids. Washington (DC) 2000.

31. Magalova T, Bella V, Brtkova A, Beno I, Kudlackova M, Volkovova K. Copper, zinc and superoxide dismutase in precancerous, benign diseases and gastric, colorectal and breast cancer. Neoplasma. 1999;46(2):100-4.

32. Boz A, Evliyaoglu O, Yildirim M, Erkan N, Karaca B. The value of serum zinc, copper, ceruloplasmin levels in patients with gastrointestinal tract cancers. The Turkish journal of gastroenterology : the 
official journal of Turkish Society of Gastroenterology. 2005;16(2):81-4.

33. Huang YL, Sheu JY, Lin TH. Association between oxidative stress and changes of trace elements in patients with breast cancer. Clinical biochemistry. 1999;32(2):131-6.

34. Golabek T, Darewicz B, Borawska M, Socha K, Markiewicz R, Kudelski J. Copper, zinc, and Cu/Zn ratio in transitional cell carcinoma of the bladder. Urologia internationalis. 2012;89(3):342-7.

35. Buntzel J, Bruns F, Glatzel M, Garayev A, Mucke R, Kisters K, et al. Zinc concentrations in serum during head and neck cancer progression. Anticancer research. 2007;27(4A):1941-3.

36. John S, Briatka T, Rudolf E. Diverse sensitivity of cells representing various stages of colon carcinogenesis to increased extracellular zinc: implications for zinc chemoprevention. Oncology reports. 2011;25(3):769-80.

37. Mazdak H, Yazdekhasti F, Movahedian A, Mirkheshti N, Shafieian M. The comparative study of serum iron, copper, and zinc levels between bladder cancer patients and a control group. International urology and nephrology. 2010;42(1):89-93.

38. Cook MB, Kamangar F, Weinstein SJ, Albanes D, Virtamo J, Taylor PR, et al. Iron in relation to gastric cancer in the Alpha-tocopherol, Beta-carotene Cancer Prevention Study. Cancer epidemiology, biomarkers \& prevention : a publication of the American Association for Cancer Research, cosponsored by the American Society of Preventive Oncology. 2012;21(11):2033-42.

39. Knekt P, Reunanen A, Takkunen $H$, Aromaa A, Heliovaara M, Hakulinen T. Body iron stores and risk of cancer. International journal of cancer. 1994;56(3):379-82.

40. Hu A, Li L, Hu C, Zhang D, Wang C, Jiang Y, et al. Serum Concentrations of 15 Elements Among Helicobacter Pylori-Infected Residents from Lujiang County with High Gastric Cancer Risk in Eastern China. Biological trace element research. 2018;186(1):21-30.

41. Mahendra A, Karishma, Choudhury BK, Sharma T, Bansal N, Bansal R, et al. Vitamin D and gastrointestinal cancer. Journal of laboratory physicians. 2018;10(1):1-5.

42. Ren C, Qiu MZ, Wang DS, Luo HY, Zhang DS, Wang ZQ, et al. Prognostic effects of 25-hydroxyvitamin D levels in gastric cancer. Journal of translational medicine. 2012;10:16.

43. Wulaningsih W, Michaelsson K, Garmo H, Hammar N, Jungner I, Walldius G, et al. Serum calcium and risk of gastrointestinal cancer in the Swedish AMORIS study. BMC public health. 2013;13:663.

44. Correa P. Human gastric carcinogenesis: a multistep and multifactorial process-First American Cancer Society Award Lecture on Cancer Epidemiology and Prevention. Cancer research. 1992;52(24):6735-40.

\section{Tables}

Table 1. Baseline characteristics of gastric cancer and control participants in a Chinese matched case-control study. 


\begin{tabular}{lccccc}
\hline Characteristics & Control (\%) & Cardia (\%) & Non-cardia (\%) & $p$ value $^{1}$ & $p$ value $^{2}$ \\
& $(\mathrm{n}=299)$ & $(\mathrm{n}=122)$ & $(\mathrm{n}=177)$ & &
\end{tabular}

\begin{tabular}{|c|c|c|c|c|c|}
\hline \multicolumn{4}{|l|}{ Sex } & \multirow[t]{3}{*}{0.45} & \multirow[t]{3}{*}{0.57} \\
\hline Male & $231(77.3)$ & $90(73.4)$ & 141 (79.7) & & \\
\hline Female & 68 (22.7) & $32(26.2)$ & 36 (20.3) & & \\
\hline Age (mean \pm std, years) & $65.7 \pm 9.3$ & $68.0 \pm 8.7$ & $65.0 \pm 10.0$ & 0.05 & 0.40 \\
\hline \multicolumn{4}{|l|}{ Age group (years) } & \multirow[t]{5}{*}{0.01} & \multirow[t]{5}{*}{0.57} \\
\hline$<55$ & 35 (11.5) & $3(2.5)$ & $24(13.6)$ & & \\
\hline $55-64$ & $108(36.3)$ & $44(36.0)$ & 67 (37.9) & & \\
\hline $65-74$ & $107(35.9)$ & $47(38.5)$ & 53 (29.9) & & \\
\hline$\geq 75$ & 49 (16.3) & $28(23.0)$ & 33 (18.6) & & \\
\hline \multicolumn{4}{|l|}{ Body mass index $\left(\mathrm{kg} / \mathrm{m}^{2}\right)$} & \multirow[t]{4}{*}{0.003} & \multirow[t]{4}{*}{$<0.0001$} \\
\hline$<18.5$ & $27(9.0)$ & $21(17.2)$ & $44(24.8)$ & & \\
\hline $18.5-24.9$ & $229(76.5)$ & $94(77.1)$ & $125(70.6)$ & & \\
\hline$\geq 25$ & $43(14.5)$ & $7(5.7)$ & 8 (4.6) & & \\
\hline \multicolumn{4}{|l|}{ Educational level (years) } & \multirow[t]{4}{*}{0.0003} & \multirow[t]{4}{*}{0.13} \\
\hline$<7$ & $200(66.8)$ & $104(85.3)$ & 134 (75.7) & & \\
\hline $7-9$ & $60(20.1)$ & 15 (12.3) & $28(15.8)$ & & \\
\hline$\geq 10$ & $39(13.1)$ & $3(2.5)$ & $15(8.5)$ & & \\
\hline \multicolumn{4}{|l|}{ Occupation } & \multirow[t]{5}{*}{0.05} & \multirow[t]{5}{*}{0.95} \\
\hline Farmer & $210(70.2)$ & $97(79.5)$ & $121(68.8)$ & & \\
\hline Industrial worker & $28(9.4)$ & $8(6.6)$ & $20(11.4)$ & & \\
\hline Office worker & $58(19.4)$ & $17(13.9)$ & $34(19.3)$ & & \\
\hline Others & $3(1.0)$ & & $1(0.6)$ & & \\
\hline \multicolumn{4}{|c|}{ Household income (Yuan/month/person) } & \multirow[t]{4}{*}{$<0.0001$} & \multirow[t]{4}{*}{$<0.0001$} \\
\hline$<600$ & $138(46.2)$ & $25(20.7)$ & $44(25.0)$ & & \\
\hline $600-1000$ & $77(25.8)$ & $41(33.9)$ & $53(30.1)$ & & \\
\hline$\geq 1000$ & $84(28.1)$ & $55(45.5)$ & $79(44.9)$ & & \\
\hline \multicolumn{4}{|l|}{ Tobacco smoking } & \multirow[t]{3}{*}{0.67} & \multirow[t]{3}{*}{0.02} \\
\hline Yes & $154(51.5)$ & $60(49.2)$ & $111(63.1)$ & & \\
\hline No & $145(48.5)$ & $62(50.8)$ & $65(36.9)$ & & \\
\hline \multicolumn{6}{|l|}{ Alcohol drinking } \\
\hline Yes & $46(15.4)$ & $11(9.0)$ & $36(20.5)$ & \multirow[t]{2}{*}{0.11} & \multirow[t]{2}{*}{0.12} \\
\hline No & $253(84.6)$ & $111(91.0)$ & $140(79.5)$ & & \\
\hline \multicolumn{4}{|c|}{ Family history of gastric cancer } & \multirow[t]{3}{*}{1.00} & 0.88 \\
\hline Yes & $53(32.9)$ & $17(33.3)$ & $22(34.4)$ & & \\
\hline No & $108(67.1)$ & $34(66.7)$ & $42(65.6)$ & & \\
\hline Chronic atrophic gastriti & & & & $<0.0001$ & 0.0001 \\
\hline Yes & $22(7.4)$ & $29(23.8)$ & 33 (18.6) & & \\
\hline No & $277(92.6)$ & $93(76.2)$ & $144(81.4)$ & & \\
\hline Reflux & & & & 0.03 & 0.07 \\
\hline Yes & $78(30.2)$ & $47(83.9)$ & $21(20.8)$ & & \\
\hline No & $180(69.8)$ & $9(16.1)$ & $80(79.2)$ & & \\
\hline
\end{tabular}

1. P value between control and cardia groups using chi-square test.

2. $\mathrm{P}$ value between control and noncardia groups using chi-square test.

Table 2. Distribution of serum level (median and interquartile) of trace elements in study population $(\mathrm{n}=594)$. 


\begin{tabular}{|c|c|c|c|c|c|}
\hline & Controls & Cardia GC & Non-cardia GC & & \\
\hline & & & & $p$ value $^{1}$ & $\begin{array}{c}p \\
\text { value }^{2}\end{array}$ \\
\hline $\begin{array}{l}\text { Cu (median, IQR, } \\
\mu \mathrm{g} / \mathrm{L})\end{array}$ & $\begin{array}{l}927.7(799.1- \\
1312.5)\end{array}$ & $\begin{array}{c}1014.6(874.4- \\
1309.2)\end{array}$ & $\begin{array}{c}1000.2(821.4- \\
1226.3)\end{array}$ & 0.0003 & 0.0009 \\
\hline Zn (median, IQR, $\mu \mathrm{g} / \mathrm{L})$ & $\begin{array}{c}605.3(492.76- \\
804.54)\end{array}$ & 545.6 (394.9-729.5) & 554.6 (428.8-761.7) & 0.47 & 0.52 \\
\hline Se (median, IQR, $\mu \mathrm{g} / \mathrm{L})$ & 92.14 (69.9-116.7) & 90.9 (63.5-112.6) & $90.2(65.5-112.6)$ & 0.28 & 0.16 \\
\hline $\begin{array}{l}\text { Mo (median, } \\
\text { IQR, } \mu \mathrm{g} / \mathrm{L})\end{array}$ & $1.8(0.93-2.79)$ & $0.93(0.72-1.14)$ & $0.93(0.78-1.14)$ & $<0.0001$ & $<0.0001$ \\
\hline $\begin{array}{l}\text { Fe (median, IQR, } \\
\mu \mathrm{g} / \mathrm{L})\end{array}$ & $\begin{array}{c}1109.8(890.0- \\
1454.3)\end{array}$ & $\begin{array}{c}925.4(809.6- \\
1121.0)\end{array}$ & $\begin{array}{c}936.6(780.3- \\
1164.8)\end{array}$ & $<0.0001$ & 0.97 \\
\hline $\begin{array}{l}\text { Ca (median, IQR, } \\
\mathrm{mg} / \mathrm{L} \text { ) }\end{array}$ & 85.1 (74.9-103.2) & 66.7 (59.1-75.2) & 68.9 (60.3-78.5) & $<0.0001$ & $<0.0001$ \\
\hline $\begin{array}{l}\text { Mg (median, IQR, } \\
\text { mg/L) }\end{array}$ & $19.1(17.9-20.6)$ & 20.1 (18.1-21.9) & 19.8 (18.2-22.1) & 0.08 & 0.11 \\
\hline $\begin{array}{l}\mathrm{Cu} / \mathrm{Zn} \text { ratio (median, } \\
\text { IQR) }\end{array}$ & 1.43 (1.07-1.84) & $2.16(1.51-2.98)$ & 1.91 (1.53-2.46) & $<0.0001$ & $<0.0001$ \\
\hline
\end{tabular}

1. $\mathrm{P}$ value comparing mean value of trace elements between controls and gastric cardia cancers; normal distribution use T-test, not-normal distribution used Wilcoxon rank-sum test.

2. $\mathrm{P}$ value comparing mean value of trace elements between controls and gastric noncardia cancers; normal distribution use T-test, not-normal distribution used Wilcoxon rank-sum test.

Table 3. Risk assessment of gastric cancer, expressed as odd ratio (OR) and 95\% confidence interval (CI) in a Chinese case-control study. 


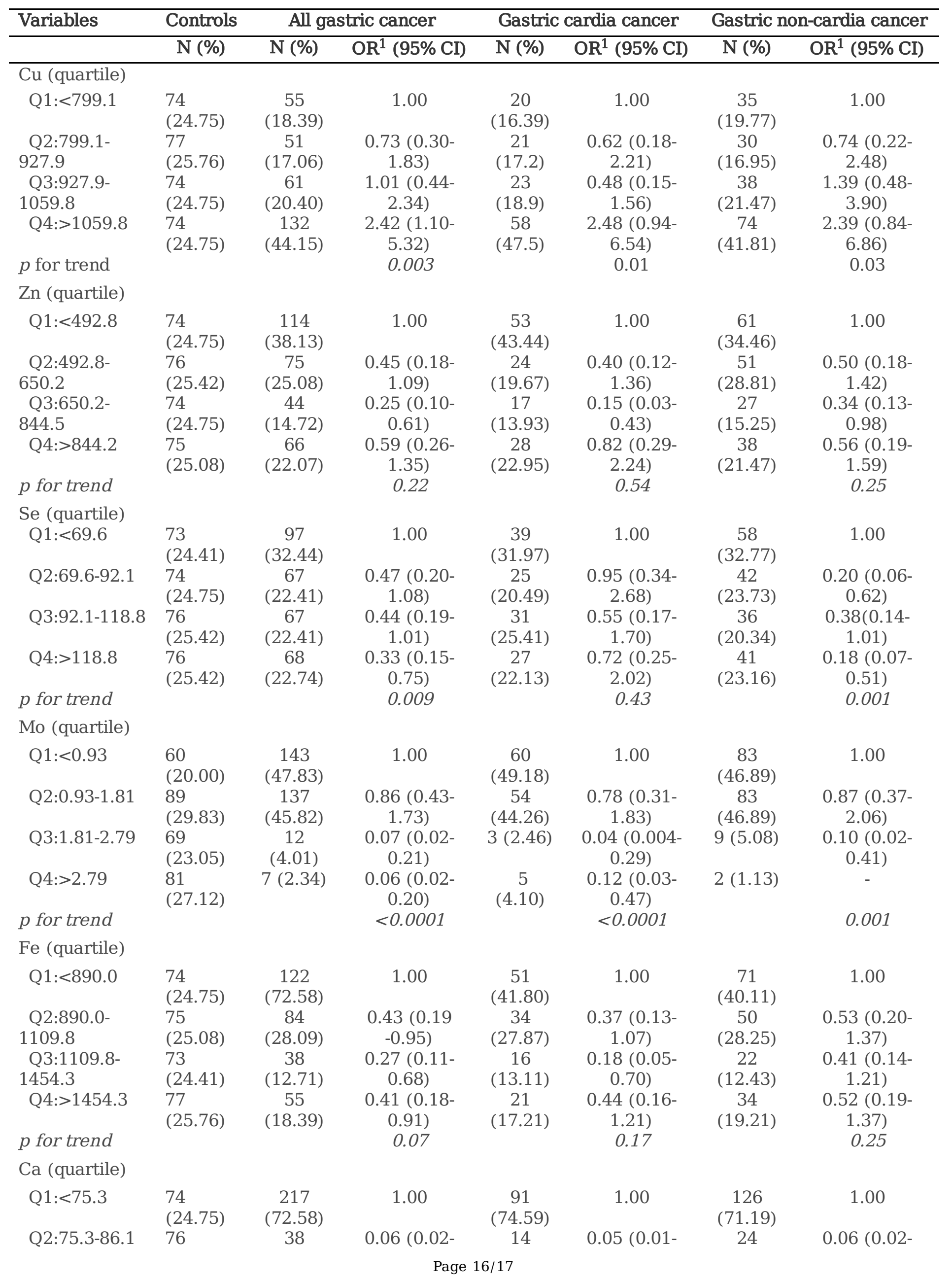




\begin{tabular}{|c|c|c|c|c|c|c|c|}
\hline & (25.42) & (12.71) & $0.16)$ & (11.48) & $0.22)$ & (13.56) & $0.27)$ \\
\hline Q3:86.1-104.5 & $\begin{array}{l}74 \\
(24.75)\end{array}$ & $\begin{array}{c}31 \\
(10.37)\end{array}$ & $\begin{array}{c}0.09(0.03- \\
0.25)\end{array}$ & $\begin{array}{c}11 \\
(9.02)\end{array}$ & $\begin{array}{c}0.04(0.01- \\
0.20)\end{array}$ & $\begin{array}{c}20 \\
(11.30)\end{array}$ & $\begin{array}{c}0.13(0.04- \\
0.40)\end{array}$ \\
\hline Q4:>104.5 & $\begin{array}{l}75 \\
(25.08)\end{array}$ & $\begin{array}{c}13 \\
(4.35)\end{array}$ & $\begin{array}{c}0.04(0.01- \\
0.11)\end{array}$ & $6(4.92)$ & $\begin{array}{l}0.06(0.01- \\
0.26)\end{array}$ & $7(3.95)$ & $\begin{array}{c}0.02(0.00- \\
0.17)\end{array}$ \\
\hline$p$ for trend & & & $<0.0001$ & & $<0.0001$ & & $<0.001$ \\
\hline \multicolumn{8}{|l|}{ Mg (quartile) } \\
\hline Q1:<17.8 & $\begin{array}{l}74 \\
(24.75)\end{array}$ & $\begin{array}{c}56 \\
(18.73)\end{array}$ & 1.00 & $\begin{array}{c}22 \\
(18.03)\end{array}$ & 1.00 & $\begin{array}{c}34 \\
(19.21)\end{array}$ & 1.00 \\
\hline Q2:17.8-19.2 & $\begin{array}{l}75 \\
(25.08)\end{array}$ & $\begin{array}{c}61 \\
(20.40)\end{array}$ & $\begin{array}{c}0.65(0.27- \\
1.58)\end{array}$ & $\begin{array}{c}27 \\
(22.13)\end{array}$ & $\begin{array}{l}0.99(0.30- \\
3.22)\end{array}$ & $\begin{array}{c}34 \\
(19.21)\end{array}$ & $\begin{array}{c}0.49(0.16- \\
1.51)\end{array}$ \\
\hline Q3:19.2-20.8 & $\begin{array}{l}76 \\
(25.42)\end{array}$ & $\begin{array}{c}69 \\
(23.08)\end{array}$ & $\begin{array}{c}1.06(0.43- \\
2.66)\end{array}$ & $\begin{array}{c}23 \\
(18.85)\end{array}$ & $\begin{array}{c}1.28(0.36- \\
4.49)\end{array}$ & $\begin{array}{c}46 \\
(25.99)\end{array}$ & $\begin{array}{c}1.02(0.34- \\
3.01)\end{array}$ \\
\hline Q4:>20.8 & $\begin{array}{l}74 \\
(24.75)\end{array}$ & $\begin{array}{c}111 \\
(37.79)\end{array}$ & $\begin{array}{c}1.31(0.59- \\
2.91)\end{array}$ & $\begin{array}{c}50 \\
(40.98)\end{array}$ & $\begin{array}{c}1.68(0.56- \\
4.84)\end{array}$ & $\begin{array}{c}63 \\
(35.59)\end{array}$ & $\begin{array}{c}1.26(0.48- \\
3.33)\end{array}$ \\
\hline$p$ for trend & & & 0.23 & & 0.25 & & 0.28 \\
\hline \multicolumn{8}{|l|}{$\begin{array}{l}\mathrm{Cu} / \mathrm{Zn} \\
\text { (quartile) }\end{array}$} \\
\hline Q1:<1.08 & $\begin{array}{l}74 \\
(24.75)\end{array}$ & $\begin{array}{c}19 \\
(6.35)\end{array}$ & 1.00 & $6(4.92)$ & 1.00 & $13(7.34)$ & 1.00 \\
\hline Q2:1.08-1.44 & $\begin{array}{l}76 \\
(25.42)\end{array}$ & $\begin{array}{c}48 \\
(16.05)\end{array}$ & $\begin{array}{c}1.75(0.54- \\
5.74)\end{array}$ & $\begin{array}{c}23 \\
(18.85)\end{array}$ & $\begin{array}{l}0.65(0.12- \\
3.52)\end{array}$ & $\begin{array}{c}25 \\
(14.12)\end{array}$ & $\begin{array}{c}4.02(0.74- \\
22.01)\end{array}$ \\
\hline Q3:1.44-1.86 & $\begin{array}{l}75 \\
(25.08)\end{array}$ & $\begin{array}{c}63 \\
(21.07)\end{array}$ & $\begin{array}{c}1.91(0.57- \\
6.37)\end{array}$ & $\begin{array}{c}17 \\
(13.93)\end{array}$ & $\begin{array}{c}1.07(0.22- \\
5.20)\end{array}$ & $\begin{array}{c}46 \\
(25.99)\end{array}$ & $\begin{array}{c}3.87(0.67- \\
22.9)\end{array}$ \\
\hline & $\begin{array}{l}74 \\
(24.75)\end{array}$ & $\begin{array}{c}169 \\
(56.52)\end{array}$ & $\begin{array}{c}11.70(3.83- \\
35.6)\end{array}$ & $\begin{array}{c}76 \\
(62.32)\end{array}$ & $\begin{array}{c}9.03(2.29- \\
35.6)\end{array}$ & $\begin{array}{c}93 \\
(52.54)\end{array}$ & $\begin{array}{c}18.82(3.50- \\
96.01)\end{array}$ \\
\hline$p$ for trend & & & $<0.0001$ & & $<0.0001$ & & $<0.0001$ \\
\hline
\end{tabular}

Adjusted for age group ( $<45,45-55,56-65,66-75, \geq 76$ years), sex (male, female), body mass index $(<18.5,18.5-$ $24.9, \geq 25 \mathrm{~kg} / \mathrm{m} 2$ ), education level ( $<7,7-9, \geq 10$ years), occupation (farmer, industrial worker, office worker, others), household income (<600, 600-1000, $\geq 1000$ Chinese Yuan/month/person), smoking (yes, no), and family history of gastric cancer (yes, no) 